\title{
An analysis of the influence of English language and literature on College Students' language competence
}

\author{
Jinju Tan \\ Department of Foreign Language ,Jingchu University of Technology, \\ Jingmen 448000, China \\ LeiwanXXX@126.com
}

\begin{abstract}
English language and literature courses in colleges and universities play an important role in daily English learning. But universities are not well aware of the role of English language and literature on the language ability of college students in the class, the proportion of English language and literature course is relatively small, in the classroom teacher is still the dominant of the classroom, in explaining the process of language and literature from, which is not conducive to improve the language ability of students. Therefore, this article from the English language and literature for the cultivation of language ability of college students, the role of English language and literature in three aspects of teaching situation of universities, improve the students' language ability in the classroom teaching of English language and literature on the recommendation of the effect on the English language and literature on language ability of college students to conduct in-depth analysis, to improve the teaching effect.

Keywords English language and literature language ability function influence teaching reform

With the development of our economy, our country is more and more closely linked with the world, and it plays an important part in the international communication. English language and literature, after a long process of development, its content is very rich. The students' English language ability is the basic quality that students need to possess. Therefore, college students should
\end{abstract}


fully realize the influence of English language and literature on College Students' language ability and improve their ability to be used the language.

\section{The role of English language and literature in the cultivation of College Students' language competence}

In the long history of the development of English language and literature, plays a huge role, is an important part of the English language. English language and literature contains a lot of content, such as the conception of literature, the skills of using language and the skills of communication. Specifically speaking, the role of English language and literature in the cultivation of College Students' language ability is mainly manifested in the following aspects.[1]

\section{1it is good for students to master the knowledge of English}

Is a process of learning literature and language learning, so in the process of learning the classical articles to the attention of some representative language, based on knowledge of the language to express the situation, focus on the use of the knowledge of English, the students master the knowledge of English plays an important role. Is mainly reflected in two aspects: on the one hand, the use of students through English literature and language learning can have a lot of words and use of some classic sentence structure, make the students' basic knowledge of English is more solid. On the other hand, through the study of English language and literature, students can learn to use different ways of expression in different contexts, so as to improve students' ability to use the English language.

For example, the famous American writer Faulkner in "the sound and the fury" wrote "Life is a tale told by an idiot full of sound and, fury signifying nothing.," "life is told some fantastic tales full of sound and fury, but cannot find a certain meaning." Many people see the charm of language was deeply impressed by this sentence, to feel the strong literary flavor. The teachers actively guide students to feel the emotion information at the same time, further analysis to this sentence structure, finally to guide students to recite, and ask the students to write in English as according to the appropriate changes to the sentence, thus becoming the most effective sentence in the article, enhance the appeal of writing.

Again, there is a saying in the famous French fairy tale "The little Prince": "I was too young to know how to love her." "I was too young, do not know how to love her." This sentence is one of the more classic statement, we feel the charm of the language in the specific context, further analysis of the classic sentence use, which mainly uses the "too... To..." sentence, express the hero for himself because of the young does not know how to cherish her. Teachers in teaching through the guidance of students to appreciate this sentence can make their own rudimentary knowledge of English more solid, and can improve their language ability.

1.2 it is helpful to improve students' language ability

At present, the main language of the peoples of the world of everyday communication and exchange in the process of English, the main purpose of learning English is to better communication, to ensure that relevant personnel to more natural and more accurately express their thoughts. The basic knowledge of English educators in the teaching of English in daily work as the focus of teaching, and neglected the cultivation of students' language application ability, 
which will cause the students although relatively solid basic knowledge of English, but in the process of communication is not able to clearly express their thoughts. At present, although various colleges and universities have to develop students' communicative ability in the learning of basic knowledge and the equally important position, but the actual teaching is no good way to improve students' communicative competence. The course of English language and literature plays an important role in improving the students"s ability of language application. Teachers can be consciously select statement more classic literary works in language and literature courses, so that students can accumulate more classic statements, so that students in the foundation has a more profound understanding of language more clearly and fully expressed.

\section{3 it is helpful to improve students' mastery of English knowledge}

English language and literature in the promotion of language use skills at the same time, to understand a variety of exquisite statements and complex usage through reading, improve the depth students to master the knowledge of English, the English language ability is more unyielding.

English article contains rich language knowledge, and this class of language knowledge on different students cannot read, read, in a specific language environment, language knowledge and vocabulary knowledge. In addition, students can learn about the customs and culture of English, improve their language ability. This classic paper as the carrier of the teaching model can effectively stimulate students' interest in learning, which for the expansion of the students basic knowledge is very beneficial to improve the students"s ability of language expression and application plays an important role.

\section{English language and Literature Teaching in Colleges and Universities}

From the teaching situation of College English language and literature at major universities will focus on basic knowledge of English teaching, English language and literature and culture become the victim of College English teaching is not conducive to the students' language ability, mainly manifested in the following aspects:

2.1Colleges and universities do not recognize the role of English language and literature in college students' language competence

At present, the major colleges and universities are influenced by traditional teaching ideas, is still the basic knowledge of learning English in the primary position, in the usual teaching still take the teacher as the dominant of the classroom, the students only belong to the passive position, this kind of teaching mode is relatively rigid, not conducive to the students to use English language ability.

2.2 the traditional teaching methods and teaching ideas are not conducive to the cultivation of students' language ability

In the traditional English language classroom, the teacher mainly introduces the life and the background of the English writers. After the classic statement in literary works analysis, and describes some language skills used in literary works to students, this teaching mode is mainly teacher centered, students complete a 
subordinate position, which is not conducive to the students' subjective to play, which is against the student-centered teaching concept.

2.3in the traditional language and literature courses, the teaching of literature is the main one and the language teaching is ignored

At present, many college English teachers feel that English language teaching is to improve students' ability to appreciate literature for English courses, ignore the language and literature course for students' practical ability training role, so the importance of literature in the teaching, teachers in the usual teaching, mainly to explain the background the content and artistic style of literary creation, and in the application of the English language, the space is relatively small, so this kind of teaching mode of English language and literature in the teaching of language and literature teaching. Besides, in order to change this situation needs to be fully aware of the two English teaching for improving students' integrated ability of english.[2]

\section{In English language and Literature Classroom Teaching to improve students' language ability}

From the above description can be seen in the English language learning for students to improve their language skills, language knowledge and solid depth plays an important role, therefore, the classroom teaching of English language and literature to improve the language ability of students has an important influence, we must take effective measures to promote the English language literature the specific study, can take the following measures.

3.1to carry out the teaching of English language and literature in the light of the ability of language application

Generally speaking the English language literature classroom teaching is the main appreciation for some classic literary works, including the author's life, writing background, works to express the core idea, the memorable paragraph appreciation etc.. In the course of learning in the classroom, the appreciation of literary works as the core, ignoring the cultivation of students' ability to use language, which does not contribute to play an important role in English language and literature courses. Therefore, teachers in the regular classroom teaching to improve students' communicative ability as the teaching focus, specifically to do the following: first, the teacher after working appreciation, guide students' independent reading, find out the most beautiful statement, student record. Second, the teacher will collect the students' statements together, after the organization students will accurately translate these statements, each statement contains, teachers on the comparison of the definitive statement for a detailed analysis, to enable students to fully understand the sentence structure. Third, the teacher assigned task, let students memorize consciously their love statements, improves the reserves of its statement. Fourth, encourage students to apply these classic statements consciously in the creation, the accuracy of the teachers to the students"s application for accurate comments, and ultimately improve the students"s ability of using language, will play an important role in English language teaching.[3] 


\section{2 organize the students to perform the scene to improve the students communicative competence}

The traditional English language teachers' classroom teaching is the main body of the class, for the study of classic literary works in the explanation given by the teacher, the students fully in accordance with the teachers' thoughts of teaching learning, students in a passive position in the English language classroom. This teaching method makes the whole process of learning is very boring, not conducive to student learning initiative, cannot really play the English language classroom teaching to improve students' communicative level of importance. Teachers should change their teaching methods actively organize students to the scene performance, teachers before class let students choose their favorite stories, such as Hamlett, in the preparation of discourse revenge before, students can appropriately adapt according to the needs of its expression. After the performance of the students in the scene, the teacher of the performance of the students to carry out appropriate comments to promote students to make appropriate changes, and ultimately improve the level of communication students. 3.3 in the classroom teaching should pay attention to mobilize the students' subjective ability

The student is the main body of the study. The teacher must achieve the good teaching effective in the teaching process, must pay attention to student's main body status. For the understanding of literary works need students to actively participate in the learning process to be able to achieve good teaching effect, and the precondition of students' subjective initiative is to realize the open classroom teaching, disadvantages of traditional fixed breakthrough, make the students can exchange their ideas, improve the students' language in each other's discussion skills.

3.4teachers pay attention to the combination of language and literature in the teaching process

The teaching of English language and literature is an important aspect of language and literature, that is, through classroom teaching to improve students' ability to use language and literary appreciation. The traditional teaching of English language and literature course will mainly focus on the teaching of literature appreciation, ignore the language application level teaching, some contents of this teaching mode can only enable the students to understand the literary works, and literary language can not be effectively, improve the students' language skills.

\section{Concluding remarks}

The final purpose of learning English is to improve students' ability of using language, the language and literature of College English classroom teaching there exist many problems, can not play the role it should have, to improve the ability of language application through literature, teachers need to language application ability as the goal, and actively mobilize the initiative of students the scene, classroom teaching, and ultimately improve the classroom teaching effect of English language and literature. 


\section{References}

[1]Nieto C, Booth M Z, Cultural Competence: Its Influence on the Teaching and Learning of International Students. Journal of Studies in International Education, 14(4),pp:406-425,2010.

[2]Henderson M, Huang H, Grant S, et al, The Impact of Chinese Language Lessons in a Virtual World on University Students' Self-Efficacy Beliefs.Australasian Journal of Educational Technology, 28(3),pp:400-419,2012. [3]Mcclarty K L, Miles J A, Evidence-Based Standard Setting Establishing a Validity Framework for Cut Scores. Educational Researcher, 42(2),pp:7888,2013 . 